\title{
Prevalence of gastrointestinal pathogens in developed and developing countries: systematic review and meta-analysis
}

\author{
Stephanie M. Fletcher, ${ }^{1}$ Mary-Louise McLaws, ${ }^{1,2}$ John T. Ellis ${ }^{1}$ \\ ${ }^{1}$ The iThree Institute and School of Medical and Molecular Biosciences, University of Technology, \\ Sydney; ${ }^{2}$ School of Public Health and Community Medicine, The University of New South Wales, \\ Sydney, Australia
}

\begin{abstract}
Significance for public health
This research is significant in that it provides an evidence base for the advancement in understanding global disease burden and the development of public health and research priorities. Understanding that people in both developed and developing settings are affected by similar pathogens to different degrees and requires cross border sharing and learning for their control. The prevalence of rotavirus underscores the need for improved access to rotavirus vaccines in both settings. Rotavirus vaccines have efficaciously reduced gastroenteritis burden where they have been introduced and hence likely to do so in developing settings. The global public health community should support efforts to make rotavirus vaccines available at affordable costs to the poorest people of the world, where disease burden and mortality is highest. Developed countries should support developing regions to implementation effective programs for the prevention and control of gastrointestinal infections, since infectious pathogens know no boundaries.
\end{abstract}

\section{Abstract}

Diarrhoeal illness is a leading cause of child mortality and morbidity worldwide. There are no precise or current estimates of the types and prevalence of pathogens associated with diarrheal illnesses in developed and developing settings. This systematic review assessed data from 60 studies published in the English language from five developing regions and developed countries worldwide to provide regional estimates of enteric pathogens affecting children. The random-effect method was used to establish the weighted average prevalence of pathogens in adults and children for each region. Significantly more pathogens were reported by studies from developing regions compared with Organisation for Economic Co-operation and Development countries $(\mathrm{P}<0.016)$. The identification rates of pathogens from community based and hospital based studies were similar $(58.5 \%$ and $58.1 \%$ respectively, $\mathrm{P}<0.619)$. The overall detection of enteric pathogens in developing countries was higher in adults (74.8\%; 95\% CI 63.1-83.8\%) compared with children (56.7\%; 95\% CI $53.0-60.4 \%)(\mathrm{P}<0.001)$. Rotavirus was the most frequently detected pathogen in all regions with the highest rate, $24.8 \%$ (95\% CI 18.0$33.1 \%$ ), detected in the developed countries. This systematic review is the first to provide an estimate of the prevalence of enteric pathogens associated with diarrhoeal illnesses in adults and children in developed and developing settings. While pathogen detection rate is greater in developing regions the consistently high prevalence of rotavirus in both developed and developing settings underscores the urgent need for access to rotavirus vaccines. Increased travel between developing and developed countries increases disease risk, and hence developed countries have a vested interest in supporting vaccine accessibility in developing settings.

\section{Introduction}

Gastrointestinal (GIT) illnesses contribute significantly to the burden of illness from infectious diseases worldwide. Diarrhoea is the second leading cause of preventable illness in children under age five. ${ }^{1-3}$ Despite the strong association between gastrointestinal illnesses and factors such as poor sanitation, inadequate access to safe drinking water and other risk factors, both resource-rich and less developed countries alike are impacted by gastrointestinal illness. ${ }^{3,4}$ The risk factors however appear to be distributed differently between developed and developing countries and as a result, the incidence of specific pathogens may differ between each setting. ${ }^{5}$ Several studies have described the pathogens, associated risk factors and the costs and burden of illness on health care. However, there are few studies that estimate the prevalence of pathogens affecting populations in different regions worldwide. Developing countries world often experience similar sanitation and poverty related risk factors, which predisposes their population to diarrhoeal illnesses. However, the incidence of illness in developed countries tend to be less generic and more related to seasonality, travel and food borne transmission. ${ }^{4}$

Several enteric micro-organisms are responsible for GIT illnesses and are bacterial, viral or parasitic in nature. ${ }^{6}$ A review of the literature world-wide indicates that a causative organism is identified in about $50 \%$ of symptomatic cases. ${ }^{7-10}$ In resource-limited settings under-reporting is possible, with the data biased towards certain pathogens and relate mainly to specific age groups. ${ }^{1,11,12}$

There are few estimates of the prevalence and distribution of pathogens that cause GIT illnesses, which indicate there may be significant differences in the prevalence of certain pathogens in circulation in developing and developed settings. ${ }^{13-15}$ Determining the prevalence of pathogens on a regional basis will assist in the development of appropriately targeted prevention and control strategies, identify gaps in surveillance and provide support for the strengthening of laboratory diagnostic capacity at the regional level. It can also assist in the management of the health needs of travelers to different regions.

This paper provides an overview of gastrointestinal illnesses and a systematic review of the literature to provide region-specific GIT pathogen detection rates associated with cases in developed countries and developing regions. Firstly, an overview of gastrointestinal illnesses including definitions, and disease transmission and risk factors are presented. Then an estimate of the detection of enteric pathogens is provided based on studies worldwide.

\section{Definition of gastrointestinal illness}

The term gastrointestinal illness refers to several conditions affecting the gastrointestinal system that exhibits watery or unformed stools and are usually caused by infections or intoxications with a biological 
agent. ${ }^{16}$ Because of the various causes, variable symptomology, and numerous different terms used to describe disease of the gastrointestinal tract, no standard definition of gastrointestinal diseases has been presented in the medical literature. ${ }^{17}$ For the purposes of this study, gastrointestinal illness refers to any illness of the gastrointestinal tract caused by a microbe causing chronic or acute diarrhea, whether or not accompanied by nausea, or vomiting, combined with abdominal pain, or systemic symptoms such as fever. A suspected case is any case having met the criteria for a clinical diagnosis (see below). A confirmed case is any suspect case that has a laboratory confirmation of an enteric disease pathogen isolated from a clinical specimen.

Diarrhoeal illness is usually divided into three main categories based on its clinical presentation: ${ }^{18}$

- Acute watery diarrhoea associated with several pathogens such as Vibrio cholera and rotavirus, usually last for several days, and poses a high risk for dehydration which can be fatal especially in young children, the elderly and immuo-compromised persons. ${ }^{18}$

- Acute bloody diarrhoea or dysentery is usually evidence of infection with Campylobacter, Salmonella, Shigella, enterohaemorrhagic $E$. coli pathotypes, Entamoeba histolytica and other organisms, and can lead to dehydration. The major risks associated with this presentation include intestinal damage, sepsis and malnutrition. ${ }^{18}$

- Persistent diarrhoea lasts for 14 or more days and is usually associated with parasitic aetiology but can be due to non-infectious causes such as inflammatory bowel disease. Due to the prolonged duration of persistent diarrhoea there is a risk of nutrient deficiency, extra intestinal infection and dehydration especially in children, the elderly and immuno-compromised. ${ }^{18}$

\section{Overview of gastrointestinal illness}

Gastrointestinal illnesses can be either acute self-limiting infections or chronic idiopathies. ${ }^{19}$ Both acute and chronic infections can be caused by pathogenic bacteria, viruses and parasites. Diarrhoea can also be caused by idiopathic diseases arising from internal dysfunctions of gastrointestinal tract include diseases such as Idiopathic bowel disease, Crohn's disease and ulcerative colitis. ${ }^{19,20}$ The majority of gastrointestinal illnesses are self-limited, ${ }^{19}$ however, certain risk factors such as malnutrition, immunosuppression, and young age predisposes the development of persistent diarrhea. ${ }^{18}$ Patients with immune deficiencies (congenital, iatrogenic or acquired) are unusually more susceptible to infections and are at an increased risk for malignancy. ${ }^{21}$

\section{Disease transmission and risk factors}

Infectious gastrointestinal illnesses are transmitted through a variety of routes including contaminated food or water borne, the faecal oral route, and person-to-person. ${ }^{16,22}$ A significant proportion, about $36 \%$, of gastrointestinal illnesses is attributable to food borne transmission. ${ }^{23,24}$ Among all illnesses attributable to food borne transmission, $30 \%$ are caused by bacteria, $3 \%$ by parasites, and $67 \%$ by viruses ${ }^{23}$ In the USA for example, nontyphoidal Salmonella spp. (35\%), norovirus (26\%), Campylobacter spp. (15\%), and Toxoplasma gondii (8\%) were the leading causes of hospitalization in 2000-2008.23,25 Salmonella, Listeria, Toxoplasma, and norovirus are responsible for more than $75 \%$ of deaths related to known causes of food borne illness each year. ${ }^{6,23,25}$ In Australia about $32 \%$ of all gastroenteritis are foodborne, and Campylobacter, non-typhoid Salmonella, pathogenic E. coli and norovirus are responsible for over $80 \%$ of foodborne illness from known pathogens. $^{26,27}$ In Australia the highest rates of gastroenteritis in the general population has been reported among young children and their adult carers. $^{28}$

The majority of gastrointestinal illnesses can be transmitted through the faecal-oral route. Infections with pathogenic $E$. coli strains are usually considered an indication of poor hygiene. Up to $63 \%$ of children with persistent diarrhoea in low and middle income countries have tested positive for E. coli strains. ${ }^{10}$ Travel-associated diarrhoea has been described and travel to a developing region is a risk factor among patients presenting with diarrhoea in developed settings. ${ }^{29,30}$ Studies have reported that travellers to low and middle income countries are between 9 and 151 times more likely to develop diarrhoeal illness, ${ }^{14,31}$ with the highest risk associated with travel to areas in South America, Africa and South Asia. ${ }^{14,32,33}$

\section{Methodology for estimating pathogen detec- tion rates}

\section{Search strategy}

Studies reporting the aetiology of diarrhoeal illness were identified from a search of databases including Science Direct, PubMed, PubMed Central, and Google scholar for articles published from 1980 and 2010. The search was not restricted to publications in the English Language, only to studies that had abstracts in English. The key subject terms included one or combinations of the following: infectious intestinal pathogen AND humans, diarrhea (or diarrhoea) and pathogen, aetiology (etiology) of acute gastroenteritis OR diarrhoea, enteric infectious pathogens. Boolean operators (not, and, or) were also used in succession to narrow and widen the searches. Other articles were identified by using the PubMed option of related articles and checked the reference lists of the original and review articles.

\section{Eligibility and study selection criteria}

Eligibility of studies for inclusion includes the following criteria:

- Detailed results of microbiological analysis of stool samples and the number of samples tested;

- Subjects defined as clinically symptomatic or asymptomatic;

- Number of study subjects and positive results for both cases/controls; Definition of symptomatic subjects (case) as persons who had diarrhoea (defined as three or more loose/watery stools in a 24 hour period), or loose stools associated with gastrointestinal symptoms including: vomiting, abdominal pain or cramps, and blood or mucus in stool..$^{34}$

Detection rates for adults and children were provided as age-specific.

\section{Excluded studies}

Studies were excluded where data were provided without adequate information for the detection and age-specific rates to be calculated, where the focus was on a single pathogen, or data were presented as the number of diarrhoeal episodes rather than samples tested.

\section{Data abstraction and analysis}

Selected studies were summarised in tabular format to include data on study design, study population, source of sample and sample size, methods to detect enteric pathogens, and detection rates. Where studies included combined age-groups that provided adequate data for children and adults separately, the data for children and adults were recorded separately. Countries were categorised into developing regions categories, based on the World Bank List of Economies published in July 2009,35 including: East Asia Pacific (EAP), Latin America and Caribbean (LAC), Middle East and Northern Africa (MENA), SubSaharan Africa (SSA), and South Asia and the Pacific (SAP). Developed 
countries were categorised based on the Organisation for Economic Co-operation and Development (OECD) category of countries. ${ }^{35,36}$ Two non-OECD developed countries [Republic of (South) Korea and Turkey] were also included in this category (Supplementary Table S1).

\section{Analysis and synthesis of results}

Estimates of the prevalence of diarrhoeal pathogens were calculated by region. As studies were conducted in different regions using different methods and approaches the pooled prevalence of pathogens was estimated using the DerSimonian-Laird random-effect (RE) method..$^{37}$ The pooled or weighted RE estimate of pathogen prevalence was calculated using the Comprehensive Meta-analysis (CMA) programme. ${ }^{38}$ The estimated mean prevalence was reported with $95 \%$ Confidence Intervals $(95 \% \mathrm{CI})$.

\section{Estimating the prevalence of gastrointestinal pathogens}

\section{Description of studies}

The search produced 10,288 papers and the abstracts of 121 were included in our critical review. Data from 60 studies (from 47 developing and 13 developed countries) met the inclusion criteria for analysis., ${ }^{7,39-97}$ The studies included are summarised in Table 1. Of the studies reviewed, one presented multi-country data (two in EAP, one in LAC, two in SAP) which was tabulated and analysed under individual country/region. ${ }^{40}$ Three studies had sufficient data to allow the tabulation and analysis of findings for children and adults separately. ${ }^{62,94,95}$ These brought the total number of studies reviewed to 67 . Most studies (73\%, $44 / 60)$ recruited subjects from hospital settings and the remainder $(17 \%, 16 / 60)$ were recruited from community or mixed settings. Studies were classified into six groups: five developing regions and OECD (developed) countries.

The summary of the laboratory procedures employed in each study is presented in Table S1. For the detection of bacteria, standard culture methods often coupled with serological tests, DNA hybridization, enzyme immunoassays (EIA) and polymerase chain reaction (PCR) were employed for the detection of different pathotypes of pathogenic E. coli. In some cases antibiotic susceptibility testing was performed by the disk diffusion or plate dilution methods. The majority of viral studies focused on rotavirus, employing mainly enzyme linked immunosorbent assay (ELISA), EIA, and less frequently, latex slide agglutination test and PCRs. Microscopic examination of permanently stained films have been generally used for the detection of ova cyst and parasites along with a modified Ziehl-Neelsen stain for coccidian parasites.

\section{Overall detection of pathogens}

\section{Source of cases}

There was no significant difference in the detection of total number of pathogens in community or hospital settings $(\mathrm{P}>0.05)$. In $13 \mathrm{com}-$ munity based studies from four regions, enteric pathogens were detected in an average of $57.8 \%$ (95\% CI, 49.2-65.9\%) of cases, ranging from $52.4 \%$ in the EAP region to $62.6 \%$ in the SSA region. There was a significant difference in detection rates from 44 hospital based studies across the six regions, $(\mathrm{P}=0.001)$. The average detection of enteric pathogens was $58.1 \%$ (95\% CI, 54.0-62.0\%) of hospitalised cases, with a range of $36.9 \%(95 \% \mathrm{CI}, 31.7-56.2 \%)$ in the MENA region to $66.7 \%$ (95\% CI, 58.9-72.4\%) in the SAP region (Table 2).

\section{Age groups}

In children, a pathogen was detected on average $56.7 \%$ ( $95 \% \mathrm{CI}, 53.0$ $60.4 \%$ ) with the lowest detection rate of $43.6 \%$ (95\% CI, 31.7-56.2\%) in the MENA region and the highest detection rate of $64.4 \%$ (95\% CI, 57.6$70.7 \%$ ) in the SAP region. Conversely, the detection rate of pathogens in adults on average was $74.8 \%$ (95\% CI, 63.1-83.8\%). The highest rate was among adults from the MENA region (90.4\%; 95\% CI, 81.2-95.4\%) and the lowest rates of detection was among adults from OECD countries (32.5\%; 95\% CI, 14.7-57.3\%) (Table 2).

\section{Regional distribution of enteric pathogens}

\section{Children}

The weighted average detection rate for enteric organisms in children for each region identified rotavirus as the most frequently detected pathogen in children (Table 3). The rates ranged from a low of $4.8 \%$ (95\% CI, 2.6-8.7\%) in SSA region to as high as $24.8 \%$ (95\% CI, 18.0$33.1 \%$ ) in OECD countries. The detection of rotavirus from diarrhoeal cases was up to five times more in OECD countries than in developing regions. Adenovirus 4.5\% (95\% CI 3.3-6.1\%) and norovirus 3.3\% (95\% CI, 1.9-5.7\%) were also most frequently detected in OECD countries when compared with developing regions. On average, E. coli pathotypes [Enterotoxigenic E. coli (ETEC), Enteropathogenic E. coli (EPEC)] and other pathogenic E. coli spp. were prevalent across all developing regions. The highest rates of EPEC were detected in the SAP region (8.5\%; 95\% CI, 5.4-13.1\%) followed by the LAC region (5.6\%; 95\% CI, 2.3-12.6\%); while ETEC was most prevalent in the SAP region and other $E$. coli pathotypes were also common in the MENA region (10.6\%; 95\% CI, 4.2-24.3\%). Campylobacter spp., was also frequently detected in developing regions with the highest rate of detection in the SAP (6.6\%; 95\% CI, 3.9-10.9) and LAC (5.5\%; 95\% CI, 2.8-10.4) regions. Salmonella spp and Shigella spp were frequently detected among children in developing regions with Salmonella (4.1\%; 95\% CI, 2.8-5.9\%) and Campylobacter spp (3.4\%; 95\% CI, 2.3-4.9\%) the most frequently detected bacterial pathogens in children in developed countries.

Parasites were less frequently detected; yet Giardia intestinalis was the most frequently detected protozoa in developing regions, with the highest prevalence found in SAP (3.0\%; 95\% CI, 1.5-5.9\%) and SSA (2.7\%; $95 \% \mathrm{CI}, 1.8-4.3 \%)$ regions. Entamoeba spp were frequently detected in MENA (1.5\%; 95\% CI, 0.6-4.2\%) and SSA (1.5\%; 95\% CI, 0.92.5\%) regions while Cryptosporidium was more prevalent in in the MENA (1.0\%; 95\% CI, 0.2-4.9\%) and SAP (1.7; 95\% CI, 0.8-3.1\%) regions. Another protozoa, Dientamoeba fragilis, was found in $<1 \%$ of cases in each region.

Adult patients were assessed for only three regions: MENA, SSA and the OECD countries (Table 4). Amongst adult patients Cryptosporidium sp. (9.4\%; 95\% CI, 1.0-50.2\%), Salmonella spp (4.0\%; 95\% CI, 0.2 43.5\%), other pathogenic E. coli (3.6\%; 95\% CI 0.3-36.2\%), and Shigella sp. (2.2\%; $95 \% \mathrm{CI}, 1.1-4.5 \%)$ were quite common in the SSA region. Frequent viral pathogens detected in stools of adults from OECD countries were norovirus $(10.5 \%$; $95 \% \mathrm{CI}, 7.5-14.7 \%)$, rotavirus $(3.6 \% ; 95 \%$ CI, 1.4-9.2\%) and Campylobacter (3.3\%; 95\% CI, 0.9-12.0\%).

\section{Discussion}

The paucity of information concerning the prevalence of diarrhoeal pathogens in different world regions has resulted in the conduct of this systematic review. This is the first study that has attempted to provide an estimate of the prevalence of enteric pathogens in both developed and developing settings. Several fundamental conclusions can be drawn from these findings. This review found i) developing regions have significantly more pathogens isolated than the OECD countries, 
Table 1. Summary of 60 studies included in the systematic review of gastrointestinal pathogens worldwide.

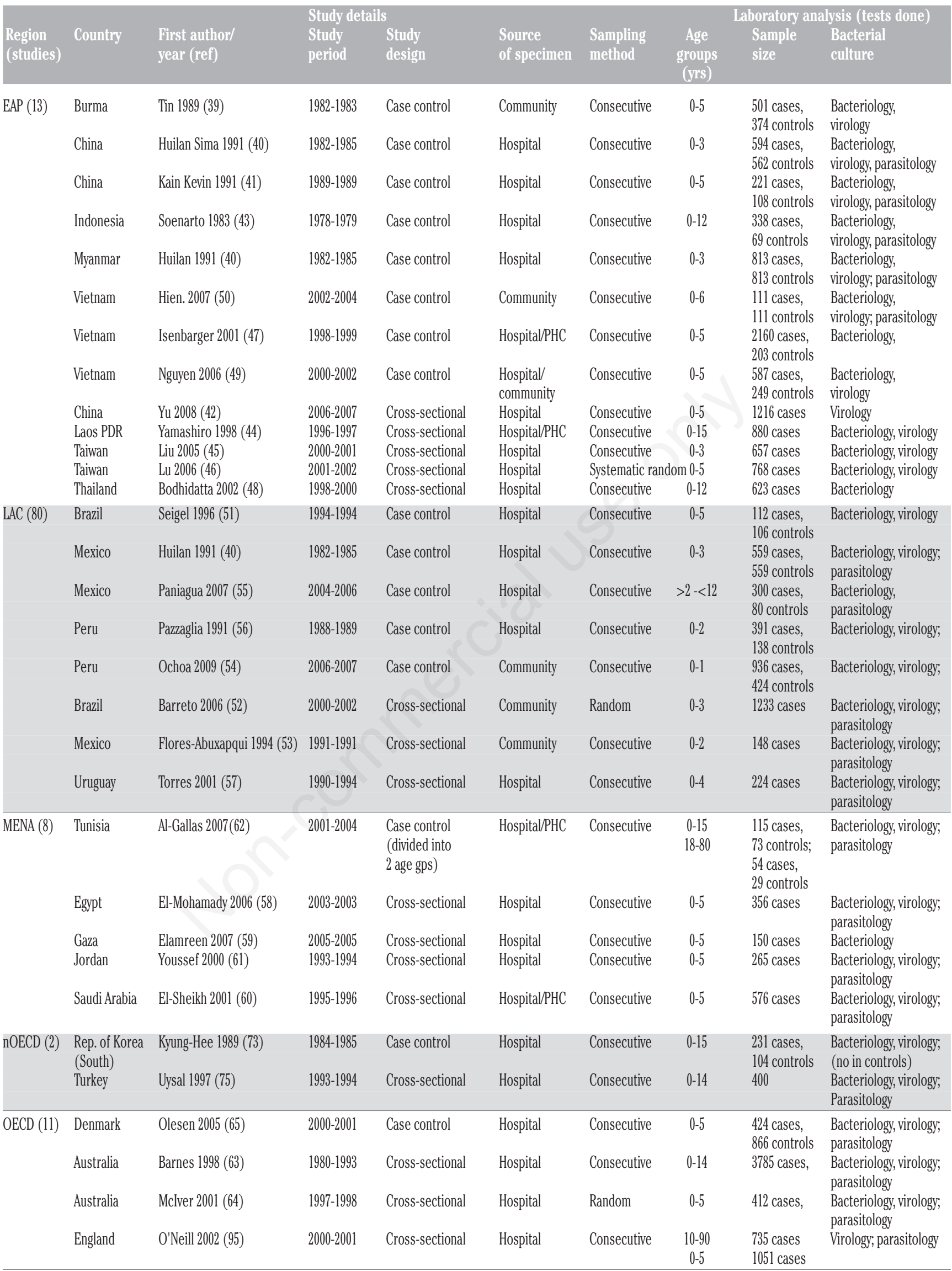

To be continued on the next page. 
Table 1. Continued from previous page.

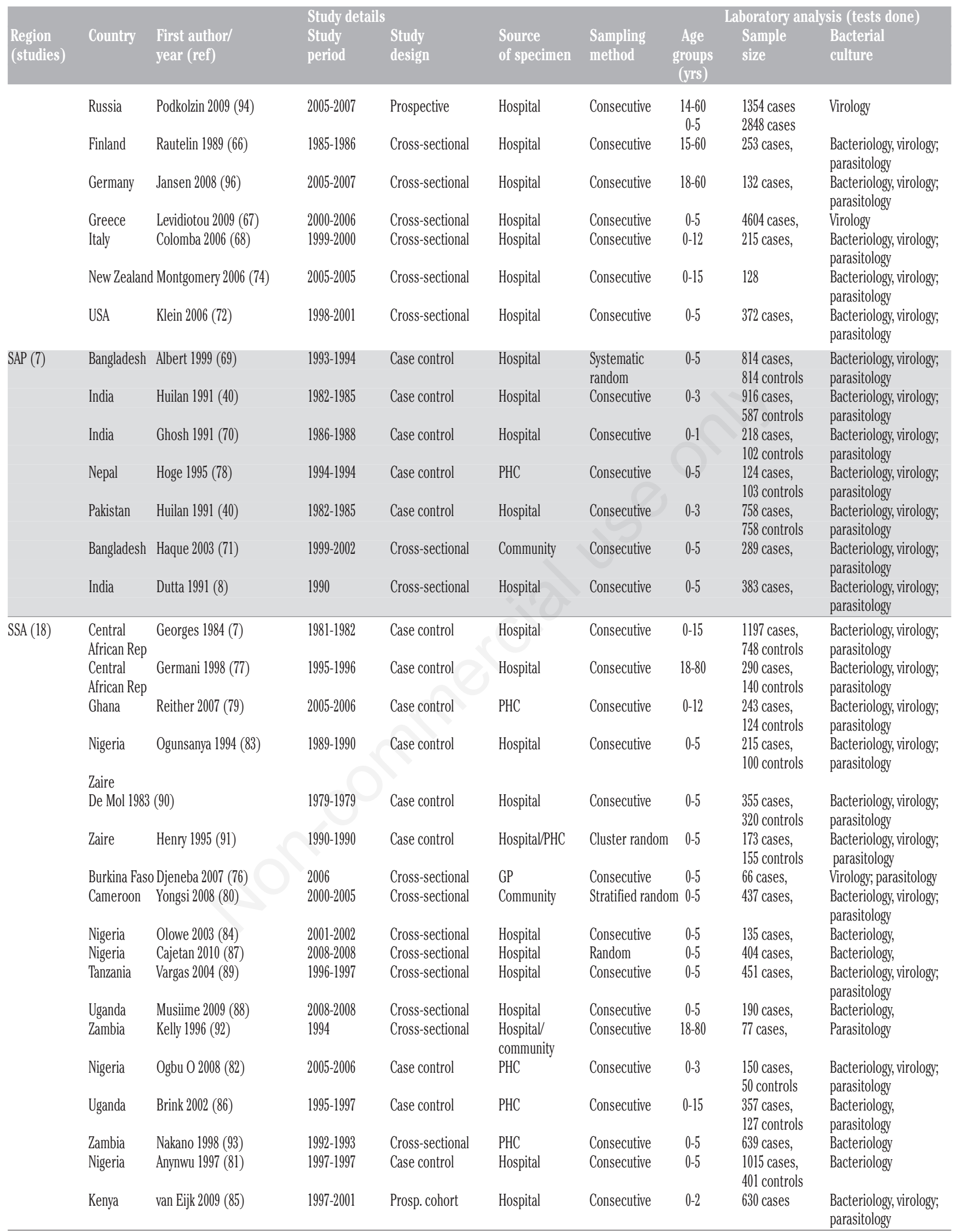

Specimens were obtained from persons seen at hospitals, Primary Health Care Centre (PHC), General Practitioner (GP), or from the community. Sampling methods include taking consecutive (or convenience or census) specimen, systematic random, random, stratified random sampling and some studies collected samples from routine surveillance programmes. Cas cont. = case control study; cross-sect. = cross sectional; Cohort = prospective follow-up studies. MENA = Middle East and North Africa; EAP= East Asia \& the Pacific; SAP= South Asia; LAC= Latin America and the Caribbean; SSA= Sub-Saharan Africa; OECD= Developed Countries including non-OECD. Source: World Bank Country Classification July 2009. Available at http:/go.worldbank.org/D7SN0B8YU0. Accessed December 29, 2009. 
ii) the identification of pathogens from community based studies was similar to those in hospital based studies, iii) the overall detection of enteric pathogens is higher amongst adults than in children in developing settings, iv) enteric viruses (rotavirus, adenovirus and norovirus) were more frequently detected in paediatric cases in developed countries than in developing countries, and v) bacterial pathogens are frequently detected amongst children and adults in developing regions.

This review found that developing regions had significantly more pathogens isolated than the OECD countries. A WHO report indicated that in 2008 the SSA and SAP regions accounted for more than three quarters of the deaths in children from diarrhoeal disease. ${ }^{11}$ Several travel based studies suggest that travel to South America, Africa, and South Asia poses the greatest risk for travelers' diarrhoea. ${ }^{14,32,33}$ South Asia continues to be affected by a disproportionately higher incidence of diarrhoeal illness in countries such as India and Bangladesh. Support to developing regions for the development of targeted interventions such as food safety programs that can successfully reduce the rates of travelers' diarrhoea amongst tourists, ${ }^{98-100}$ and provide evi-

Table 2. Age specific and source related regional estimate of overall pathogen detection.

\begin{tabular}{|c|c|c|c|c|c|c|c|c|}
\hline \multirow{2}{*}{$\begin{array}{l}\text { Overall } \\
\text { detection rate } \\
\text { Regions }\end{array}$} & \multicolumn{2}{|c|}{ Children } & \multicolumn{2}{|c|}{ Adults } & \multicolumn{2}{|c|}{ All cases } & \multirow{2}{*}{$\begin{array}{c}\text { Hospital } \\
\text { Detection rate \% } \\
(95 \% \mathrm{CI})\end{array}$} & \multirow{2}{*}{$\begin{array}{c}\text { Community } \\
\text { Detection rate \% } \\
(95 \% \mathrm{CI})\end{array}$} \\
\hline & $\begin{array}{l}\text { Number } \\
\text { of studies }\end{array}$ & $\begin{array}{c}\text { Detection } \\
\text { rate }(95 \% \mathrm{CI})\end{array}$ & $\begin{array}{l}\text { Number of } \\
\text { studies }\end{array}$ & $\begin{array}{l}\text { Detection } \\
\text { rate } \%(95 \% \mathrm{CI})\end{array}$ & $\begin{array}{l}\text { Number of } \\
\text { studies }\end{array}$ & $\begin{array}{l}\text { Detection } \\
\text { rate \% }(95 \% \mathrm{CI})\end{array}$ & & \\
\hline SAP & 7 & $64.4(57.6-70.7)$ & 0 & $N / R$ & 13 & $54.1(43.9-63.9)$ & $66.7(58.3-74.1)$ & $58.7(55.6-61.7)$ \\
\hline LAC & 8 & $61.0(51.2-70.1)$ & 0 & $\mathrm{~N} / \mathrm{R}$ & 8 & $61.0(51.2-70.1)$ & $65.0(56.3-72.8)$ & $52.6(35.6-69.1)$ \\
\hline SSA & 16 & $59.4(48.5-69.3)$ & 2 & $69.7(39.6-89.0)$ & 6 & $54.5(40.2-68.1)$ & $52.8(39.9-65.4)$ & $62.6(43.3-78.6)$ \\
\hline EAP & 13 & $54.1(43.9-63.9)$ & 0 & $\mathrm{~N} / \mathrm{R}$ & 7 & $64.4(57.6-70.7)$ & $59.4(49.7-68.5)$ & $52.5(27.7-76.1)$ \\
\hline MENA & 5 & $43.6(31.7-56.2)$ & 1 & $90.4(81.2-95.4)$ & 18 & $60.5(50.6-69.7)$ & $36.9(22.0-54.9)$ & $N / R$ \\
\hline OECD & 11 & 50.1 (42.5-57.7) & 4 & $32.5(14.7-57.3)$ & 15 & $45.2(37.2-53.5)$ & $50.4(42.5-58.3)$ & $\mathrm{N} / \mathrm{R}$ \\
\hline Total & 60 & $56.7(53.0-60.4)$ & 7 & 74.8 (63.1-83.8) & 67 & $57.2(53.4-60.9)$ & $58.1(54.0-62.0)$ & $58.5(55.6-61.4)$ \\
\hline
\end{tabular}

Random-Effect estimate [Q (df) P-value] for difference between hospital and community based studies $=0.25$ (1) 0.619 ; Adults = (20.7 (2) 0.001 and children $=13.2$ (5) 0.022 ; regions $=13.9$ (5) 0.016 . The weighted mean detection rate is calculated by dividing number of positive stool tests for individual pathogens by the total number of specimen tested. DerSimonian-Laird random-effect (RE) method was calculated on the basis of the Cochran's Q-test with alpha set at the 5\% level. Regions: EAP=East Asia \& the Pacific; MENA = Middle East and North Africa; SAP= South Asia; LAC= Latin America and the Caribbean; SSA= Sub-Saharan Africa; $\mathrm{OECD}=$ Developed Countries including non-OECD developed countries. $\mathrm{N} / \mathrm{R}=$ not reported.

Table 3. Weighted average prevalence of enteric pathogens from children 0-12 years in developing regions and OECD countries.

\begin{tabular}{|c|c|c|c|c|c|c|}
\hline $\begin{array}{l}\text { N. of studies (60) } \\
\text { Pathogens }\end{array}$ & $\begin{array}{c}\text { EAP } \\
13 \\
\text { Detection rate \% } \\
(95 \% \mathrm{CI})\end{array}$ & $\begin{array}{c}\text { LAC } \\
8 \\
\text { Detection rate \% } \\
(95 \% \mathrm{CI})\end{array}$ & $\begin{array}{c}\text { MENA } \\
5 \\
\text { Detection rate \% } \\
(95 \% \mathrm{CI})\end{array}$ & $\begin{array}{c}\text { OECD } \\
11 \\
\text { Detection rate \% } \\
(95 \% \mathrm{CI})\end{array}$ & $\begin{array}{c}\text { SAP } \\
7 \\
\text { Detection rate \% } \\
(95 \% \mathrm{CI})\end{array}$ & $\begin{array}{c}\text { SSA } \\
16 \\
\text { Detection rate \% } \\
(95 \% \mathrm{CI})\end{array}$ \\
\hline \multicolumn{7}{|c|}{ Bacteria } \\
\hline Aeromonas & $0.1(0.0-0.6)$ & $0.3(0.00-6.9)$ & $0.7(0.3-1.9)$ & $0.1(0.04-0.2)$ & $2.9(1.4-6.1)$ & $0.3(0.2-0.6)$ \\
\hline Campylobacter jejuni & $2.1(1.0-4.2)$ & $5.5(2.8-10.4)$ & $2.4(1.1-5.5)$ & $3.4(2.3-4.9)$ & $6.6(3.9-10.9)$ & $2.7(1.5-4.8)$ \\
\hline EPEC & $2.9(1.7-4.8)$ & $5.6(2.3-12.6)$ & $1.4(0.3-6.6)$ & $0.2(0.1-0.9)$ & $8.5(5.4-13.1)$ & $3.2(2.0-5.2)$ \\
\hline ETEC & $4.1(2.2-7.5)$ & $5.9(3.1-11.2)$ & $5.4(1.7-15.6)$ & $0.1(0.01-1.6)$ & $12.7(8.6-18.3)$ & $1.0(0.5-2.1)$ \\
\hline Other diarrh E. coli pathotypes & $1.7(0.8-3.4)$ & $1.9(0.5-6.8)$ & $10.6(4.2-24.3)$ & $0.4(0.1-1.2)$ & $1.8(0.5-5.6)$ & $4.3(2.1-8.6)$ \\
\hline Salmonella spp. & $2.8(1.5-5.4)$ & $1.7(0.3-9.2)$ & $3.2(1.6-6.5)$ & $4.1(2.8-5.9)$ & $2.5(1.6-3.8)$ & $3.6(2.5-5.0)$ \\
\hline Shigella spp. & $4.4(2.8-7.0)$ & $2.9(1.4-6.1)$ & $3.5(2.4-5.3)$ & $0.5(0.1-2.1)$ & $5.6(3.0-10.1)$ & $4.3(2.6-7.0)$ \\
\hline Vibrio cholerae & $0.2(0.1-0.4)$ & $0.2(0.1-0.5)$ & $0.2(0.1-0.7)$ & $0.1(0.04-0.3)$ & $2.1(1.0-4.8)$ & $0.4(0.1-0.9)$ \\
\hline \multicolumn{7}{|c|}{ Viruses } \\
\hline Astrovirus & $0.1(0.0-0.6)$ & $0.4(0.2-0.8)$ & $0.2(0.1-0.7)$ & $1.3(0.7-2.7)$ & $0.1(0.04-0.3)$ & $0.2(0.1-0.7)$ \\
\hline Adenovirus type 40/41 & $0.4(0.2-0.9)$ & $0.5(0.2-1.6)$ & $0.2(0.1-0.7)$ & $4.5(3.3-6.1)$ & $1.5(0.6-3.4)$ & $0.5(0.2-1.5)$ \\
\hline Norovirus & $0.2(0.1-0.7)$ & $0.3(0.1-1.6)$ & $0.2(0.1-0.7)$ & $3.3(1.9-5.7)$ & $0.7(0.3-1.8)$ & $0.2(0.1-0.9)$ \\
\hline Rotavirus & $12.1(7.4-19.3)$ & $12.0(7.4-19.0)$ & $14.4(7.8-25.0)$ & $24.8(18.0-33.1)$ & $7.9(4.7-12.8)$ & $4.8(2.6-8.7)$ \\
\hline \multicolumn{7}{|c|}{ Parasites } \\
\hline Ascaris & $0.2(0.0-0.7)$ & $0.3(0.1-1.0)$ & $0.5(0.2-1.1)$ & $0.1(0.04-0.2)$ & $0.1(0.04-0.3)$ & $0.3(0.1-1.1)$ \\
\hline Blastocystis spp. & $0.1(0.0-0.2)$ & $0.1(0.1-0.4)$ & $0.2(0.1-0.7)$ & $0.1(0.04-0.5)$ & $0.1(0.04-0.3)$ & $0.2(0.1-0.3)$ \\
\hline Cryptosporidium sp & $0.1(0.1-0.2)$ & $0.2(0.1-2.0)$ & $1.0(0.2-4.9)$ & $0.3(0.1-0.5)$ & $1.7(0.8-3.1)$ & $0.3(0.1-0.9)$ \\
\hline Dientamoeba fragilis & $0.1(0.1-0.2)$ & $0.1(0.1-0.4)$ & $0.2(0.1-0.7)$ & $0.1(0.03-0.2)$ & $0.1(0.1-0.3)$ & $0.2(0.1-0.3)$ \\
\hline Entamoeba spp. & $0.1(0.1-0.9)$ & $0.6(0.1-6.5)$ & $1.5(0.6-4.2)$ & $0.1(0.03-0.4)$ & $0.6(0.1-2.5)$ & $1.5(0.9-2.5)$ \\
\hline Giardia intestinalis & $0.1(0.1-0.3)$ & $1.9(0.6-6.5)$ & $1.2(0.5-3.2)$ & $0.3(0.1-0.8)$ & $3.0(1.5-5.9)$ & $2.7(1.8-4.3)$ \\
\hline
\end{tabular}

EAP=East Asia \& the Pacific; MENA = Middle East and North Africa; SAP= South Asia; LAC= Latin America and the Caribbean; SSA= Sub-Saharan Africa; OECD= Developed Countries including non-OECD developed countries. EPEC- Enteropathogenic E. coli; ETEC- Enterotoxigenic E. coli. 
dence for vaccine development should be a priority for developed countries. ${ }^{101}$ While the source of difference in pathogen prevalence between both settings cannot be determined from the information provided in the studies, we suggest that it is likely to be related, in part, to factors such as socioeconomic status, access to potable water and sanitation solutions. These factors were not explicitly described in many studies but are known important predictors of diarrhoea incidence in developing settings. ${ }^{102}$

The identification of pathogens from community based studies was similar to those in hospital based studies; however regional differences may exist between the settings. Even though there were no significant differences in the overall detection of pathogens between community and hospital based studies, differences were observed within hospital based studies between regions. One explanation for this may be hospital setting cases have severe clinical symptoms and were more likely to be tested compared with cases from the community setting.

The overall detection of enteric pathogens was higher amongst adults than in children in developing settings. The contrary is true for developed settings. Whilst this may be due to underlying sample sizes and testing methodologies employed, there is some evidence to suggest that several new and emerging pathogens are not routinely detected in clinical laboratories. Considering the majority of the studies involving children were from developing regions, limited laboratory capacity may have precluded the identification of organisms that require very sensitive diagnostic techniques, such as viral pathogens and some enteric protozoa. ${ }^{103-106}$ There is a need for the development of inexpensive sensitive and specific diagnostic methods to improve pathogen detection in clinical laboratories. ${ }^{15,107-110}$ Some exposures increase the risk for infections in older children and adults, that could influence the types of pathogens that infect them including poor hygiene practices, foodborne infections and different environmental risk factors. ${ }^{111}$

Enteric viruses were more frequently detected in paediatric cases in developed countries than in developing countries. This finding is not unusual since rotavirus is considered to be the most common cause of childhood diarrhoea in both developed and developing countries. ${ }^{112}$ Infections with enteric viruses have a strong relationship with seasons and may be the reason for the higher incidence in OECD countries. This relationship is particularly evident in OECD countries with a temperate climate where rotavirus and norovirus infections often peak in the cooler months. ${ }^{113,114}$ There is a less obvious seasonal distribution in tropical countries. ${ }^{115}$ The burden of rotaviral diarrhoea worldwide has resulted in the World Health Organization (WHO) placing priority on the development and distribution of rotavirus vaccines globally. ${ }^{3}$ More recently, a gradually decrease in the number of hospitalizations from severe dehydrating diarrhoea in children has been observed since the introduction of the rotavirus vaccine in the USA, in $2006,{ }^{116}$ and in Australia in 2007..17-119 Efficacy trials conducted in Africa, ${ }^{120}$ and a post-marketing study conducted in Mexico, support the use of rotavirus vaccines in the developing countries. ${ }^{121}$

Norovirus infection in developed settings was prevalent in adults and nearly three times more common compared with children. Norovirus is recognized as a leading cause of epidemic gastroenteritis affecting all age groups, with sporadic cases occurring all year round with increased incidence observed in colder months. ${ }^{113}$ In contrast to

Table 4. Weighted average prevalence of enteric pathogens from adults $>12$ years in developing regions and OECD countries.

\begin{tabular}{|c|c|c|c|}
\hline $\begin{array}{l}\text { Regions } \\
\text { No. of Studies (7) } \\
\text { Pathogens }\end{array}$ & $\begin{array}{c}\text { MENA } \\
1 \\
\text { Detection rate \% }(95 \% \mathrm{CI})\end{array}$ & $\begin{array}{c}\text { OECD } \\
4 \\
\text { Detection rate } \%(95 \% \mathrm{Cl})\end{array}$ & $\begin{array}{c}\text { SSA } \\
2 \\
\text { Detection rate } \%(95 \% \mathrm{CI})\end{array}$ \\
\hline \multicolumn{4}{|c|}{ Bacteria } \\
\hline Aeromonas sp. & $0.7(0.01-9.9)$ & $0.2(0.01-0.6)$ & $0.3(0.01-2.3)$ \\
\hline Campylobacter jejuni & $1.4(0.2-9.1)$ & $3.3(0.9-12.0)$ & $0.3(0.01-2.3)$ \\
\hline EPEC & $\mathrm{N} / \mathrm{R}$ & $0.1(0.01-0.5)$ & $0.3(0.01-2.3)$ \\
\hline ETEC & $N / R$ & $0.1(0.01-0.5)$ & $1.0(0.3-2.7)$ \\
\hline Other diarrh E. coli pathotypes & $37(26.7-48.6)$ & $0.1(0.01-0.5)$ & $3.6(0.3-36.2)$ \\
\hline Salmonella spp. & $0.7(0.01-9.9)$ & $1.9(0.4-7.7)$ & $4.0(0.2-43.5)$ \\
\hline Shigella spp. & $4.1(1.3-12.0)$ & $0.2(0.01-1.0)$ & $2.2(1.1-4.5)$ \\
\hline Vibrio cholerae & $0.7(0.01-9.9)$ & $0.1(0.01-0.5)$ & $N / R$ \\
\hline \multicolumn{4}{|c|}{ Viruses } \\
\hline Astrovirus & $0.7(0.01-9.9)$ & $0.4(0.01-2.9)$ & $0.3(0.01-2.3)$ \\
\hline Adenovirus type 40/41 & $6.8(2.9-15.4)$ & $1.0(0.4-2.4)$ & $0.3(0.01-2.3)$ \\
\hline Norovirus & $0.7(0.01-9.9)$ & $10.5(7.5-14.7)$ & $0.3(0.01-2.3)$ \\
\hline Rotavirus & $1.4(0.2-9.1)$ & $3.6(1.4-9.2)$ & $0.3(0.01-2.3)$ \\
\hline \multicolumn{4}{|c|}{ Parasites } \\
\hline Ascaris & $0.7(0.01-9.9)$ & $0.1(0.01-0.5)$ & $0.3(0.01-2.3)$ \\
\hline Blastocystis spp. & $0.7(0.01-9.9)$ & $0.2(0.01-1.5)$ & $4.0(0.5-24.7)$ \\
\hline Cryptosporidium sp & $0.7(0.01-9.9)$ & $0.3(0.01-3.1)$ & $9.4(1.0-50.2)$ \\
\hline Dientamoeba fragilis & $0.7(0.01-9.9)$ & $0.1(0.01-0.5)$ & $0.3(0.01-2.3)$ \\
\hline Entamoeba spp. & $1.4(0.2-9.1)$ & $0.2(0.01-0.6)$ & $2.5(1.2-5.1)$ \\
\hline Giardia intestinalis & $0.7(0.01-9.9)$ & $0.3(0.01-2.3)$ & $1.4(0.6-3.2)$ \\
\hline
\end{tabular}

EAP=East Asia \& the Pacific; MENA = Middle East and North Africa; SAP= South Asia; LAC= Latin America and the Caribbean; SSA= Sub-Saharan Africa; OECD= Developed Countries including non-OECD developed countries. EPEC- Enteropathogenic E. coli; ETEC- Enterotoxigenic E. coli. 
rotavirus, norovirus is the principal cause of healthcare associated viral diarrhoea. ${ }^{122}$ Enteric adenoviruses types 40 and 41 and astrovirus are less frequently implicated but are also important causes of acute diarrhoeal illnesses in sporadic and outbreak settings. ${ }^{114,122}$

Campylobacter spp, E. coli pathotypes and Shigella spp are frequently detected in children from developing regions while adults are predominantly affected by Cryptosporidium spp, Salmonella and pathogenic $E$. coli. Bacterial diarrhoea can be spread through various routes including contaminated food, water and the faecal-oral route; providing multiple sources of infections among the exposed. ${ }^{6,28}$ The relatively high prevalence of different strains of pathogenic $E$. coli found in both adults and children in developing settings has been previously described..$^{10}$ One recent estimate of multiple diarrhoea pathogens in older children and adults in outpatient and inpatient settings, found ETEC and Vibrio cholera as the leading causes of hospitalization and Salmonella sp, Shigella sp, and $E$. hystolitica as the leading causes in out-patients. ${ }^{123}$ The prevalence of pathogenic $E$. coli in developed countries is usually sporadic and more closely associated with travel to a developing regions. ${ }^{29,30,112}$ Campylobacter spp and Salmonella spp were the most common bacteria isolated in patients from OECD countries. Evidence from the USA, New Zealand and Australia suggest that Salmonella infections are a major cause of hospitalizations and deaths annually, and are frequently associated with foodborne illnesses in industrialized countries. ${ }^{124-126}$

Enteric protozoa, mainly Giardia intestinalis and Entamoeba spp were common in children from developing regions compared with children from developed settings. A recent meta-analysis found that Giardia intestinalis was not associated with acute paediatric diarrhoea but was associated with persistent diarrhoea in developing countries. Adults, predominantly those in the SSA region, were mainly affected by Cryptosporidium spp and Blastocystis spp., which has been previously described in the SSA region. ${ }^{22}$ The prevalence of parasitic infections is consistent with findings from other developing settings, where sanitation and access to clean water is compromised. ${ }^{127-129}$ There are conflicting interpretations about the role of Blastocystis spp as a pathogen, and as a result some laboratories may not place priority on looking for or reporting the presence of this parasite. ${ }^{130-132}$ However, several reports have established its association with abdominal pain, persistent diarrhoea and irritable bowel syndrome, ${ }^{133-135}$ and other reports hypothesize that pathogenicity may be sub-type dependent. ${ }^{136}$ between the prevalence of enteric pathogens and seasons in different countries. However, previous studies have shown correlations between the prevalence of some pathogens and specific seasons. For example, studies have described distinct seasonal patterns of increased prevalence of viral enteric infections in cooler months. ${ }^{50,139-141}$ Despite regional variations, consistent summer peak in the incidence of bacterial diseases has been observed across transnational boundaries, for campylobacteriosis, salmonellosis and verotoxin producing $E$. coli (VTEC). ${ }^{142}$ This consistent summer peak in bacterial diseases has been widely described for both developing and developed suggesting possible direct effects of large-scale environmental influences on a shared exposure routes. ${ }^{143-147}$ For example increased incidence of infection with common foodborne bacteria (e.g. Campylobacter, Salmonella spp) has been reported in warmer months. ${ }^{148,149}$ Understanding disease specific seasonal patterns is important for improving existing disease surveillance methods and developing appropriate prevention strategies.

\section{Conclusions}

This systematic review of the literature has attempted to provide an estimation of the types and prevalence of gastrointestinal pathogens associated with diarrhoeal illness in both developing and developed settings. To our knowledge this systematic review is the first to provide an estimate of the region specific prevalence of enteric pathogens associated with diarrhoeal illnesses in both developed and developing countries. Similar studies to provide a comparison were not found as this was the first study to employ a broad definition of diarrhoeal illness, for adults and children. The current study addresses the gap in the literature by providing region specific estimates of pathogen prevalence for adults and children worldwide. It concludes that pathogens are consistently detected in persons seeking medical attention for diarrhoeal illnesses in secondary or primary care settings. This review highlights the need for the development of inexpensive sensitive and specific diagnostic methods to improve pathogen detection in clinical laboratories. Global support is necessary for equitable access to rotavirus vaccines in developing settings and for continued research and development of cost effective interventions to prevent and control diarrhoeal illnesses worldwide.

\section{Limitations}

In systematically reviewing the literature, it became apparent that only some studies utilised high level study design and analytical techniques that could identify a broad range of enteric pathogens. Accordingly, we limited our analysis to include only those studies that utilised a rigorous methodology and clearly defined the patient group (diarrhea cases) and the enteric pathogens detected. This study found a higher prevalence of enteric viruses in developed countries compared with developing countries. This difference however, might be due to the different methods used to identify viral pathogens in the different geographical areas, since some diagnostic methods are more sensitive than others. Similar findings however have been found by the recently completed GEMS study that employed a standardised protocol for several countries in sub-Saharan Africa and Asia. ${ }^{103,137,138}$ Additionally, OECD countries are likely to have better testing regimes than many developing countries, and as such they are more likely to identify pathogens from infected persons. As such, care should be taken in making comparisons across developed and developing regions. Another limitation of this study was the lack of data to analyse the correlation

Correspondence: Dr. Stephanie M. Fletcher, The iThree Institute and School of Medical and Molecular Biosciences, University of Technology, Sydney P.O. Box 123, Broadway, NSW, Australia.

E-mail: stephanie.fletcher@uts.edu.au

Key words: adults, bacteria, children, developing country, diarrhoea, enteric pathogens, vaccines, viruses, parasites.

Conflict of interests: the authors declare no potential conflict of interests.

Received for publication:8 April 2013.

Accepted for publication: 14 May 2013.

(C) Copyright S.M. Fletcher et al., 2013

Licensee PAGEPress, Italy

Journal of Public Health Research 2013; 2:e9

doi:10.4081/jphr.2013.e9

This work is licensed under a Creative Commons Attribution NonCommercial 3.0 License (CC BY-NC 3.0). 


\section{References}

1. Kosek M, Bern C, Guerrant R. The global burden of diarrhoeal disease, as estimated from studies published between 1992 and 2000. Bull World Health Organ 2003;81:197-204.

2. Black RE, Cousens S, Johnson HL, et al. Global, regional, and national causes of child mortality in 2008: a systematic analysis. Lancet 2010;375:1969-87.

3. Wardlaw T, Salama P, Brocklehurst C, et al. Diarrhoea: why children are still dying and what can be done. Lancet 2010;375:870-2.

4. UNICEF/WHO. Diarrhoea: why children are still dying and what can be done. UNICEF/WHO joint report on preventing and treating the second leading killer of children. 2009. Available from: http://www.unicef.org/health/index_51412.html. Accessed on May 2013.

5. Keusch G, Fontaine 0, Bhargava A, et al. Diarrhoeal Diseases 2006. Available from: http://files.dcp2.org/pdf/DCP/DCP19.pdf.

6. Schmidt RH, Goodrich RM, Archer DL, Schneider KR. General overview of the causative agents of foodborne illness. 2003. Food Science and Human Nutrition Department, Florida Cooperative Extension Service, IFAS, University of Florida. Available from: http://edis.ifas.ufl.edu/pdffiles/FS/FS09900.pdf.

7. Georges MC, Wachsmuth IK, Meunier DMV, Nebout N. Parasitic, bacterial and viral enteric pathogens associated with diarrhoea in Central African Republic. J Clin Microbiol 1984;19:571-5.

8. Dutta P, Lahiri M, Sen D, Pal S. Prospective hospital based study on persistent diarhoea. Gut 1991;32:787-90.

9. Boga JA, Melon S, Nicieza I, et al. Etiology of sporadic cases of pediatric acute gastroenteritis in Asturia, Spain, and genotyping and characterization of norovirus strains involved. J Clin Microbiol 2004;42:2668-74.

10. Abba K, Sinfield R, Hart CA, Garner P. Pathogens associated with persistent diarrhoea in children in low and middle income countries: systematic review. BMC Infect Dis 2009;9:88-103.

11. Boschi-Pinto C, Velebit L, Shibuya K. Estimating mortality due to diarrhoea indeveloping countries. Bull World Health Organ 2008;86:710-7.

12. Green ST, Small MJ, Casman EA. Determinants of national diarrheal disease burden. Environ Sci Technol 2009;43:993-9.

13. Savarino SJ, Bourgeois AL. Epidemiology of diarrhoeal diseases in developed countries. Trans R Soc Trop Med Hyg 1993;87 Suppl 3:711.

14. Greenwood Z, James Black, Leisa Weld, et al. Gastrointestinal Infection Among International Travelers Globally. J Travel Med 2008;15:221-8.

15. Fletcher SM, Stark D, Harkness J, Ellis J. Enteric protozoa in the developed world: a public health perspective. Clin Microbiol Rev 2012;25:420-49.

16. Gilbert GL. Improving foodborne disease surveillance in NSW. NSW Public Health Bull 2008;19:1-2.

17. Roy SL, Scallan E, J BM. The rate acute gastrointestinal illness in developed countries. J Water Health 2006;4 Suppl 2:31-69.

18. Heymann DL, ed. Control of communicable diseases manual. 19 ed. Washington DC: American Public Health Association; 2008.

19. Lamps LW. Infective disorders of the gastrointestinal tract. Histopathology 2007;50:55-63.

20. Pintér M, Kolesárová M. Genetic aspects of idiopatic inflammatory bowel disease Acta medica (Hradec Králové) Supplementum Universitas Carolina, Facultas Medica Hradec Králové 2004;47:837.

21. Ferrell LD. Sexually Transmitted Gastrointestinal Tract Diseases. West J Med 1984;141:96.

22. Fletcher SM, Stark D, Ellis J. Prevalence of gastrointestinal pathogens in Sub-Saharan Africa; systematic review and metaanalysis. J Pub Health Africa 2011;2:127-37.

23. Mead P, Slutsker L, Dietz V, et al. Food-related illness and death in the United States. Emerg Infect Dis 1999;5:607-25.

24. Flint JA, Van Duynhoven YT, Angulo FJ, et al. Estimating the burden of acute gastroenteritis, foodborne disease, and pathogens commonly transmitted by food: an international review. Clin Infect Dis 2005;41:698-704.

25. Scallan E, Hoekstra RM, Angulo FJ, et al. Foodborne illness acquired in the United States - major pathogens. Emerg Infect Dis 2011;17:7-15.

26. Hall G, Martyn D. Niels Becker K, et al. Estimating foodborne gastroenteritis, Australia. Emerg Infect Dis 2005;11:1257-64.

27. Kirk Martyn D, McKay I, Hall Gill V, et al. Food safety: foodborne disease in Australia: the OzFoodNet experience. Clin Infect Dis 2008;47:392-400.

28. Australian Government Department of Health and Ageing. Foodborne illness in Australia. Annual incidence circa 2000. 2005. Available from: http://www.ozfoodnet.gov.au/internet/ozfoodnet/ publishing.nsf/Content/7BDEF9F8EC3835D9CA257165001AB31D/ \$File/foodborne_report.pdf.

29. Leung A, Robson W, Davies H. Travelers' diarrhea. Adv Ther 2006;23:519-27.

30. Marcos LA, DuPont HL. Advances in defining etiology and new therapeutic approaches in acute diarrhea. J Infect 2007;55:385-93.

31. Swaminathan A, Torresi J, Schlagenhauf P, et al. A global study of pathogens and host risk factors associated with infectious gastrointestinal disease in returned international travellers. J Infect 2009;59:19-27.

32. Steffen R, Tornieporth N, Clemens S-AC, et al. Epidemiology of travelers' diarrhea: details of a global survey. J Travel Med 2004;11:231-8.

33. Jiang Z-D, Brett L, Verenkar MP, Ashley D. Prevalence of enteric pathogens among international travelers with diarrhea acquired in Kenya (Mombasa), India (Goa), or Jamaica (Montego Bay). J Infect Dis 2002;185:497.

34. WHO. Health topics: diarrhoea. World Health Organization; 2010. Available from: http://www.who.int/topics/diarrhoea/en/.

35. The World Bank Group. World Bank Country Classifcation. July 2009. Available from: http://go.worldbank.org/D7SN0B8YU0.

36. International Monetary Fund. World Economic Outlook. Database WEO Groups and Aggregates Information. World Economic and Financial Surveys [serial on the Internet]. 2009: Available from: http://www.imf.org/external/pubs/ft/weo/2009/02/weodata/groups.h tm\#ae.

37. Jackson D, Bowden J, Baker R. How does the DerSimonian and Laird procedure for random effects meta-analysis compare with its more efficient but harder to compute counterparts? J Stat Plann Infer 2010;140:961-70.

38. Borenstein M, Hedges L, Higgins J, Rothstein H. Comprehensive Meta-analysis Version 2. Englewood NJ Biostat; 2005. Available from: http://www.meta-analysis.com/downloads/Meta-AnalysisManual.pdf.

39. Tin A, Mar N, Kyi K, et al. Epidemiology and aetiology of acute childhood diarrhoea in Burma: a rural community survey. Trans $\mathrm{R}$ Soc Trop Med Hyg 1989;83:827-30.

40. Huilan S, Zhen LG, Mathan MM, et al. Etiology of acute diarrhoea among children in developing countries: a multicentre study in five countries. Bull World Health Organ 1991;69:549-55.

41. Kain KC, Barteluk RL, Kelly MT, et al. Etiology of childhood diarrhea in Beijing, China. J Clin Microbiol 1991;29:90-5.

42. Yu J-M, Li D-D, Xu Z-Q, et al. Human bocavirus infection in children hospitalized with acute gastroenteritis in China. J Clin Virol 2008;42:280-5. 
43. Soenarto Y, Sebodo T, Suryantoro P, et al. Bacteria, parasitic agents and rotaviruses associated with acute diarrhoea in hospital in-patient Indonesian children. Trans R Soc Trop Med Hyg 1983;77:724-30.

44. Yamashiro T, Nakasone N, Higa N, et al. Etiological study of diarrheal patients in Vientiane, Lao People's Democratic Republic. J Clin Microbiol 1998;36:2195-9.

45. Liu LJ, Yang YJ, Kuo PH, et al. Diagnostic value of bacterial stool cultures and viral antigen tests based on clinical manifestations of acute gastroenteritis in pediatric patients. Eur J Clin Microbiol Infect Dis 2005;24:559-61.

46. Lu C-Y, Tsai-Ling L, Fang Y-H, et al. Disease burden and related medical costs of rotavirus infections in Taiwan. BMC Infect Dis 2006;6:176.

47. Isenbarger $\mathrm{D}$, Hien $\mathrm{B}, \mathrm{Ha} \mathrm{H}$, et al. Prospective study of the incidence of diarrhoea and prevalence of bacterial pathogens in a cohort of Vietnamese children along the Red River. Epidemiol Infect 2001;127:229-36.

48. Bodhidatta L, Vithayasai N, Eimpokalarp B, et al. Bacterial enteric pathogens in children with acute dysentery in Thailand: increasing importance of quinolone-resistant Campylobacter. Southeast Asian J Trop Med Public Health 2002;33:752-7.

49. Nguyen TV, Le Van P, Le Huy C, et al. Etiology and epidemiology of diarrhea in children in Hanoi, Vietnam. Int $\mathrm{J}$ Infect Dis 2006;10:298-308.

50. Hien BTT, Trang DT, Scheutz F, et al. Diarrhoeagenic Escherichia coli and other causes of childhood diarrhoea: a case control study in children living in a wastewater-use area in Hanoi, Vietnam. J Med Microbiol 2007;56:1086-96.

51. Seigel RR, Santana e Sant'anna C, Salgado K, de Jesus P. Acute diarrhea among children from high and low socioeconomic communities in Salvador, Brazil. Int J Infect Dis 1996;1:28-34.

52. Barreto ML, Milroy CA, Strina A, et al. Community-based monitor ing of diarrhea in urban Brazilian children: incidence and associated pathogens. Trans R Soc Trop Med Hyg 2006;100:234-42.

53. Flores-Abuxapqui JJ, Suárez-Hoil GdJ, Puc-Franco MA, et al. Etiology of acute diarrhea in hospital in-patient mexican children. Revista Biomedica 1994;5:117-25.

54. Ochoa TJ, Ecker L, Barletta F, et al. Age-related susceptibility to infection with diarrheagenic Escherichia coli among infants from Periurban Areas in Lima, Peru. Clin Infect Dis 2009;49:1694-702.

55. Paniagua G, Monroy E, García-González 0, et al. Two or more enteropathogens are associated with diarrhoea in Mexican children. Ann Clin Microbiol Antimicrob 2007;6:17.

56. Pazzaglia G, Sack RB, Salazar E, et al. High frequency of coinfecting enteropathogens in Aeromonas-associated diarrhea of hospitalized Peruvian infants. J Clin Microbiol 1991;29:1151-6.

57. Torres ME, Pírez MC, Schelotto F, et al. Etiology of children's diarrhea in Montevideo, Uruguay: associated pathogens and unusual isolates. J Clin Microbiol 2001;39:2134-9.

58. El-Mohamady H, Abdel-Messih IA, Youssef FG, et al. Enteric pathogens associated with diarrhea in children in Fayoum, Egypt. Diagn Microbiol Infect Dis 2006;56:1-5.

59. Elamreen FHA, Abed AA, Sharif FA. Detection and identification of bacterial enteropathogens by polymerase chain reaction and conventional techniques in childhood acute gastroenteritis in Gaza, Palestine. Int J Infect Dis 2007;11:501-7.

60. El-Sheikh SM, El-Assouli SM. Prevalence of viral, bacterial and parasitic enteropathogens among young children with acute diarrhoea in Jeddah, Saudi Arabia. J Health Popul Nutr 2001;19:25-30.

61. Youssef M, Shurman A, Bougnoux M-E, et al. Bacterial, viral and parasitic enteric pathogens associated with acute diarrhea in hospitalized children from northern Jordan. FEMS Immunol Med Microbiol 2000;28:257-63.
62. Al-Gallas N, Bahri 0, Bouratbeen A, et al. Etiology of acute diarrhea in children and adults in Tunis, Tunisia, with emphasis on diarrheagenic Escherichia coli: prevalence, phenotyping, and molecular epidemiology. Am J Trop Med Hyg 2007;77:571-82.

63. Barnes GL, Uren E, Stevens KB, Bishop RF. Etiology of acute gastroenteritis in hospitalized children in Melbourne, Australia, from April 1980 to March 1993. J Clin Microbiol 1998;36:133-8.

64. McIver CJ, Hansman G, White P, et al. Diagnosis of enteric pathogens in children with gastroenteritis. Pathology 2001;33:353-8.

65. Olesen B, Neimann J, Böttiger B, et al. Etiology of diarrhea in young children in Denmark: a case-control study. J Clin Microbiol 2005 43:3636-41.

66. Rautelin HI, Renkonen OV, Von Bonsdorff C-H, et al. Prospective study of the etiology of diarrhea in adult outpatients and inpatients. Scand J Gastroenterol 1989;24:329-33.

67. Levidiotou S, Gartzonika C, Papaventsis D, et al. Viral agents of acute gastroenteritis in hospitalized children in Greece. Clin Microbiol Infect 2009;15:596-8.

68. Colomba C, De Grazia S, Giammanco GM, et al. Viral gastroenteritis in children hospitalised in Sicily, Italy. Eur J Clin Microbiol Infect Dis 2006;25:570-5.

69. Albert MJ, Faruque ASG, Faruque SM, et al. Case-control study of enteropathogens associated with childhood diarrhea in Dhaka, Bangladesh. J Clin Microbiol 1999;37:3458-64.

70. Ghosh AR, Nair GB, Dutta P, et al. Acute diarrhoeal diseases in infants aged below six months in hospital in Calcutta, India: an aetiological study. Trans R Soc Trop Med Hyg 1991;85:796-8.

71. Haque R, Mondal D, Kirkpatrick BD, et al. Epidemiologic and clinical characteristics of acute diarrhoea with emphasis on entamoeba histolytica infections in preschool children in an urban slum of Dhaka, Bangladesh. Am J Trop Med Hyg 2003;69:398-405.

72. Klein E, Boster DR, Stapp JR, et al. Diarrhea etiology in a children's hospital emergency department: a prospective cohort study. Clin Infect Dis 2006;43:807-13.

73. Kyung-Hee K, Inn-Soo Suh, Jung Mogg Kim, et al. Etiology of childhood diarrhoea in Korea. J Clin Microbiol 1989;27:1192-6.

74. Neuwelt P, Simmons G. A public health portrait of severe paediatric gastroenteritis in the Auckland region: report of the 2005 Auckland Paediatric Gastroenteritis Investigation. Auckland: Auckland Regional Public Health Service; 2006. Available from: https://researchspace.auckland.ac.nz/bitstream/handle/2292/8273/PaedsGastro_Apr06.pdf?sequence=2.

75. Uysal G, Do ru Ü, Aysev D, Karabiber N. Campylobacter jejuni gastroenteritis in Turkish children. Infection 1997;25:159-62.

76. Djeneba 0, Damintoti K, Denise I, et al. Prevalence of rotavirus adenovirus and enteric parasites amongst paediatric patients attending Saint Camille Medical Centre in Ouagadougou. Pak J Biol Sci 2007;10:4266-70.

77. Germani Y, Minssart P, Vohito M, et al. Etiologies of acute, persistent, and dysenteric diarrheas in adults in Bangui, Central African Republic, in relation to human immunodeficiency virus serostatus. Am J Trop Med Hyg 1998;59:1008-14.

78. Hoge CW, Echeverria P, Rajah R, et al. Prevalence of Cyclospora species and other enteric pathogens among children less than 5 years of age in Nepal. J Clin Microbiol 1995;33:3058-60.

79. Reither K, Ignatius R, Weitzel T, et al. Acute childhood diarrhoea in northern Ghana: epidemiological, clinical and microbiological characteristics. BMC Infect Dis 2007;7:104.

80. Yongsi HBN. Pathogenic microorganisms associated with childhood diarrhoea in low-and-middle income countries: case study of Youande-Cameroon. Int J Environmen Res Public Health 2008;5: 213-29.

81. Anyanwu BN. The aetiologic agents of bacterial diarrhoea in the 
children of the former East Central State of Nigeria. Int J Environ Health Res 1997;7:215-32.

82. Ogbu 0, Agumadu N, Uneke CJ, Amadi ES. Aetiology of acute infantile diarrhoea in the south-Eastern Nigeria: an assessment of microbiological and antibiotic sensitivity profile. Internet $\mathbf{J}$ Third World Med 2008;7:2.

83. Ogunsanya TI, Rotimi VO, Adenuga A. A study of the aetiological agents of childhood diarrhoea in Lagos, Nigeria. J Med Microbiol 1994;40:10-4.

84. Olowe OA, Olayemi AB, Eniola KIT, Adeyeba OA. Aetiology agents of diarrhoea in children under five years of age in Osogbo, Osun State. Afr J Clin Exper Microbiol 2003;4:62-6.

85. van Eijk AM, Brooks JT, Adcock PM, et al. Diarrhea in children less than two years of age with known HIV status in Kisumu, Kenya. Int J Infect Dis 2010;14:e220-5.

86. Brink AK, Mahé $\mathrm{C}$, Watera $\mathrm{C}$, et al. Diarrhoea, cd4 counts and enteric infections in a community-based cohort of hiv-infected adults in Uganda. J Infect 2002;45:99-106.

87. Cajetan ICI, Nnennaya IR, Casmir AA, Florence IN. Enteric bacteria pathogens associated with diarrhoea of children in the federal capital territory Abuja, Nigeria. New York Sci J 2010;3.

88. Musiime V, Kalyesubula I, Kaddu-Mulindwa D, Byarugaba J. Enteric bacterial pathogens in hiv-infected children with acute diarrhea in Mulago referral and teaching hospital, Kampala, Uganda. J Int Assoc Physicians AIDS Care 2009;8:185-90.

89. Vargas M, Gascon J, Casals C, et al. Etiology of diarrhea in children less than five years of age in Ifakara, Tanzania. Am J Trop Med Hyg 2004;70:536-9.

90. De Mol P, Hemelhof W, Butzler JP, et al. Enteropathogenic agents in children with diarrhoea in rural Zaire. Lancet 1983;321:516-8.

91. Henry M-C, Alary M, Desmet P, et al. Community survey of diarrhooea in children under five years in Kinshasa Zaire. Ann Soc Belge Med Trop 1995;75:105-14.

92. Kelly P, Baboo K, Wolff M, et al. The prevalence and aetiology of persistent diarrhoea in adults in urban Zambia. Acta Tropica 1996;61:183-90.

93. Nakano T, Kamiya H, Matsubayashi N, et al. Diagnosis of bacterial enteric infections in children in Zambia. Acta Paediatr Jpn 1998;40:259-63.

94. Podkolzin AT, Fenske EB, Yu Abramycheva N, et al. Hospital-based surveillance of rotavirus and other viral agents of diarrhea in children and adults in Russia, 2005-2007. J Infect Dis 2009;200 Suppl 1:S228-33.

95. O'Neill HJ, McCaughey C, Coyle PV, et al. Clinical utility of nested multiplex RT-PCR for group F adenovirus, rotavirus and norwalklike viruses in acute viral gastroenteritis in children and adults. $\mathrm{J}$ Clin Virol 2002;25:335-43.

96. Jansen A, Stark K, Kunkel J, et al. Aetiology of communityacquired, acute gastroenteritis in hospitalised adults: a prospective cohort study. BMC Infect Dis 2008;8:143.

97. Olsen JE, Aabo S, Hill W, et al. Probes and polymerase chain reaction for detection of food-borne bacterial pathogens. Int J Food Microbiol 1995;28:1-78.

98. Ashley DVM, Walters C, Dockery-Brown C, et al. Interventions to prevent and control food-borne diseases associated with a reduction in traveler's diarrhea in tourists to Jamaica. J Travel Med 2004;11:364-9.

99. Fletcher SM, Maharaj SR, James K. Description of the food safety system in hotels and how it compares with HACCP standards. J Travel Med 2009;16:35-41.

100. Steffen R, Collard F, Tornieporth N, et al. Epidemiology, etiology, and impact of traveler's diarrhea in Jamaica. JAMA 1999;281:8117 .

101. Sanchez-Padilla E, Grais RF, Guerin PJ, et al. Burden of disease and circulating serotypes of rotavirus infection in sub-Saharan Africa: systematic review and meta-analysis. Lancet Infect Dis 2009;9:567-76.

102. Genser B, Strina A, Dos Santos LA, et al. Impact of a city-wide sanitation intervention in a large urban centre on social, environmental and behavioural determinants of childhood diarrhoea: analysis of two cohort studies. Int J Epidemiol 2008;37:831-40.

103. Robins-Browne RM, Levine MM. laboratory diagnostic challenges in case/control studies of diarrhea in developing countries. Clin Infect Dis 2012;55 Suppl 4:S312-S6.

104. Richardson S, Grimwood K, Gorrell R, et al. Extended excretion of rotavirus after severe diarrhoea in young children. Lancet 1998;351:1844-8.

105. Stark D, van Hal S, Fotedar R, et al. Comparison of stool antigen detection kits to PCR for diagnosis of amebiasis. J Clin Microbiol 2008;46:1678-81.

106. Bruijnesteijn van Coppenraet LES, Wallinga JA, Ruijs GJHM, et al Parasitological diagnosis combining an internally controlled realtime PCR assay for the detection of four protozoa in stool samples with a testing algorithm for microscopy. Clin Microbiol Infect 2009;15:869-74.

107. Stark D, Al-Qassab SE, Barratt JLN, et al. Evaluation of multiplex tandem real-time PCR for detection of Cryptosporidium spp., Dientamoeba fragilis, eEntamoeba histolytica, and Giardia intestinalis in clinical stool samples. J Clin Microbiol 2011;49:25762.

108. Stark D, Barratt J, Roberts T, et al. A Review of the clinical presentation of dientamoebiasis. Am J Trop Med Hyg 2010;82:614-9.

109. Stark D, Barratt J, Roberts T, et al. Comparison of microscopy, two xenic culture techniques, conventional and real-time PCR for the detection of Dientamoeba fragilis in clinical stool samples. Eur J Clin Microbiol Infect Dis 2010;29:411-6.

110. Fotedar R, Stark D, Beebe N, et al. Laboratory diagnostic techniques for Entamoeba species. Clin Microbiol Rev 2007;20:511-32.

111. Putignani L, Menichella D. Global distribution, public health and clinical impact of the protozoan pathogen Cryptosporidium. Interdiscip Perspect Infect Dis 2010;2010:1-39.

112. Thapar N, Sanderson PIR. Diarrhoea in children: an interface between developing and developed countries. Lancet 2004;363:641-53.

113. Glass R. Parashar UD, Estes M. Norovirus gastroenteritis. N Engl J Med 2009;361:1776-85.

114. Fletcher SM, Van Hal S, Andresen D, et al. Gastrointestinal pathogen distribution in symptomatic children in Sydney, Australia. J Epidemiol Global Health 2012;3:11-21.

115. Cook SM, Glass RI, LeBaron CW, Ho M-S. Global seasonality of rotavirus infections. Bull World Health Organ 1990;68:171-7.

116. Curns AT, Steiner CA, Barrett M, et al. Reduction in acute gastroenteritis hospitalizations among US children after introduction of rotavirus vaccine: analysis of hospital discharge data from 18 US States. J Infect Dis 2010;201:1617-24.

117. Chiu C, Dey A, Wang H, et al. Vaccine preventable diseases in Australia, 2005 to 2007. Commun Dis Intell Q Rep. 2010;34 Supp:S1-167.

118. NCIRS, Brotherton J, Wang H, et al. Vaccine preventable diseases and vaccination coverage in Australia, 2003 to 2005. Commun Dis Intell Q Rep 2007;31 Suppl:S1-152.

119. Hull BP, Mahajan D, Dey A, et al. Immunisation coverage annual report, 2008. Commun Dis Intell Q Rep 2010;34:241-58.

120. Madhi SA, Cunliffe NA, Steele D, et al. Effect of human rotavirus vaccine on severe diarrhea in African infants. $\mathrm{N}$ Engl $\mathrm{J}$ Med 2010;362:289-98

121. Santosham M. Rotavirus vaccine - a powerful tool to combat deaths from diarrhea. N Engl J Med 2010;362:358-60. 
122. Svraka S, Duizer E, Vennema H, et al. Etiological role of viruses in outbreaks of acute gastroenteritis in The Netherlands from 1994 through 2005. J Clin Microbiol 2007;45:1389-94.

123. Fischer Walker CL, Sack D, Black RE. Etiology of diarrhea in older children, adolescents and adults: a systematic review. PLoS Negl Trop Dis 2010;4:e768.

124. Voetsch AC, Van Gilder TJ, Angulo FJ, et al. FoodNet estimate of the burden of illness caused by nontyphoidal salmonella infections in the United States. Clin Infect Dis 2004;38 Suppl 3:S127-34.

125. Rabsch W, Tschäpe H, Bäumler AJ. Non-typhoidal salmonellosis: emerging problems. Microb Infect 2001;3:237-47.

126. Bambrick H, Dear K, Woodruff R, et al. The impacts of climate change on three health outcomes: temperature-related mortality and hospitalisations, salmonellosis and other bacterial gastroenteritis, and population at risk from dengue. June 2008. Available from: http:/garnautreview.org.au/CA25734E0016A131/Web0bj/03AThreehealthoutcomes/\$File/03-A\%20Three\%20health\%20outcomes.pdf.

127. O'Ryan M, Prado V, Pickering LK. A millennium update on pediatric diarrheal illness in the developing world. Sem Pediatr Infect Dis 2005;16:125-36.

128. Raso G, Luginbuhl A, Adjoua CA, et al. Multiple parasite infections and their relationship to self-reported morbidity in a community of rural Cote d'Ivoire. Int J Epidemiol 2004;33:1092-102.

129. Mor Siobhan M, Tzipori S. Cryptosporidiosis in Children in SubSaharan Africa: a lingering challenge. Clin Infect Dis 2008;47:91521.

130. Stark D, Barratt JLN, van Hal S, et al. Clinical significance of enteric protozoa in the immunosuppressed human population. Clin Microbiol Rev 2009;22:634-50.

131. Jones M, Whipps C, Ganac R, et al. Association of Blastocystis subtype 3 and 1 with patients from an Oregon community presenting with chronic gastrointestinal illness. Parasitol Res 2009;104:3415 .

132. Boorom K, Smith H, Nimri L, et al. Oh my aching gut: irritable bowel syndrome, Blastocystis, and asymptomatic infection. Parasites Vectors 2008;1:40.

133. Dogruman-Al F, Kustimur S, Yoshikawa H, et al. Blastocystis subtypes in irritable bowel syndrome and inflammatory bowel disease in Ankara, Turkey. Mem Inst Oswaldo Cruz 2009;104:724-7.

134. Stark D, van Hal S, Marriott D, et al. Irritable bowel syndrome: a review on the role of intestinal protozoa and the importance of their detection and diagnosis. Int J Parasitol 2007;37:11-20.

135. Jimenez-Gonzalez D, Martinez-Flores W, Reyes-Gordillo J, et al. Blastocystis infection is associated with irritable bowel syndrome in a Mexican patient population. Parasitol Res 2011:1-7.
136. Roberts T, Stark D, Harkness J, Ellis J. Subtype distribution of Blastocystis isolates identified in a Sydney population and pathogenic potential of Blastocystis. Eur J Clin Microbiol Infect Dis 2012;32:1-9.

137. Kotloff KL, Blackwelder WC, Nasrin D, et al. The global enteric multicenter study (GEMS) of diarrheal disease in infants and young children in developing countries: epidemiologic and clinical methods of the case/control study. Clin Infect Dis 2012;55 Suppl 4:S232-S45.

138. Panchalingam S, Antonio M, Hossain A, et al. Diagnostic microbiologic methods in the GEMS-1 case/control study. Clin Infect Dis 2012;55 Suppl 4:S294-S302.

139. Fletcher SM, Van Hal S, Andresen D, et al. Gastrointestinal pathogen distribution in symptomatic children in Sydney, Australia. J Epidemiol Global Health 2012;3:11-21

140. Grimwood K, Huang QS, Cohet C, et al. Rotavirus hospitalisation in New Zealand children under 3 years of age. J Paediatr Child Health 2006;42:196-203.

141. Mounts AW, Ando T, Koopmans M, et al. Cold weather seasonality of gastroenteritis associated with Norwalk-like viruses. J Infect Dis 2000;181 Suppl 2:S284-S7.

142. Lal A, Hales S, French N, Baker MG. Seasonality in human zoonotic enteric diseases: a systematic review. PLoS One 2012;7:e31883.

143. Chan SSW, Ng KC, Lam PK-W, et al. Predictors of positive stool culture in adult patients with acute infectious diarrhea. J Emerg Med 2002;23:125-30.

144. Ekdahl K, De Jong B, Wollin R, Andersson Y. Travel-associated non-typhoidal salmonellosis: geographical and seasonal differences and serotype distribution. Clin Microbiol Infect 2005;11:13844.

145. Ekdahl L, Andersson Y. The epidemiology of travel-associated shigellosis-regional risks, seasonality and serogroups. J Infect 2005;51:222-9.

146. Gauci C, Gilles H, O'Brien S, et al. The magnitude and distribution of infectious intestinal disease in Malta: a population-based study. Epidemiol Infect 2007;135:1282-9.

147. Hall G, Kirk M, Ashbolt R, et al. Frequency of infectious intestinal illness in Australia, 2002: regional, seasonal and demographic variation. Epidemiol Infect 2006;134:111-8.

148. Kovats RS, Edwards SJ, Charron D, et al. Climate variability and campylobacter infection: an international study. Int J Biometeorol 2005;49:207-14.

149. Pardhan-Ali A, Wilson J, Edge VL, et al. A descriptive analysis of notifiable gastrointestinal illness in the Northwest Territories, Canada, 1991-2008. BMJ Open 2012;2:e000732. 